
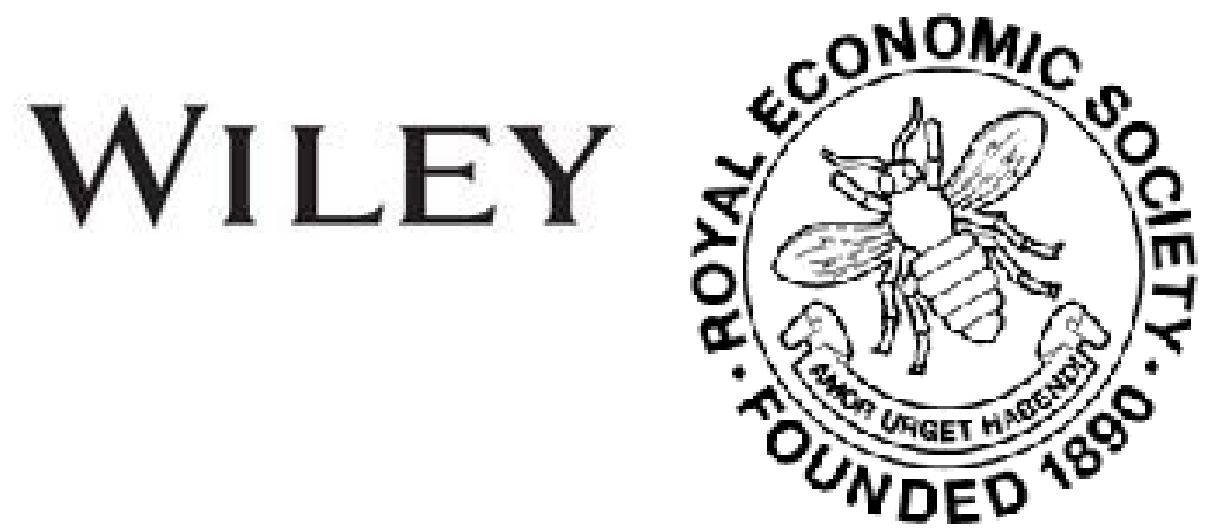

The Agricultural Crisis

Author(s): Giuseppe M. Fiamingo

Source: The Economic Journal, Vol. 8, No. 30 (Jun., 1898), pp. 259-264

Published by: Wiley on behalf of the Royal Economic Society

Stable URL: http://www.jstor.org/stable/2957372

Accessed: 27-06-2016 07:22 UTC

Your use of the JSTOR archive indicates your acceptance of the Terms \& Conditions of Use, available at

http://about.jstor.org/terms

JSTOR is a not-for-profit service that helps scholars, researchers, and students discover, use, and build upon a wide range of content in a trusted digital archive. We use information technology and tools to increase productivity and facilitate new forms of scholarship. For more information about JSTOR, please contact support@jstor.org.

Wiley, Royal Economic Society are collaborating with JSTOR to digitize, preserve and extend access to The Economic Journal 
the pattern of self-denying virtue for all Englishmen to copy? $\mathrm{Mr}$. Albu's question may then take the form: "Do you think a common miner with a wife and three children is justified in taking two rooms, if he can only afford to pay for one?"

The old issues between Capital and Labour must sooner or later be raised in the Transvaal and other parts of South Africa. While confronted by the common enemy in the shape of an unprogressive Boer Government, they seem to have interests absolutely identical. But this is only a passing phase of that economic development which will ultimately array in opposing camps forces which now stand united. Already there are signs of the coming split. The labour agitator has made his appearance, and miners speak of combination against the capitalists in the event of the latter shutting down the mines. Expropriation by the Government has even been urged by some of the more daring spirits, who claim that this is the only way of equalising the risks incidental to gold-mining, and so preventing the recurrence of industrial crises. Whether such a solution be desirable or not, it is very unlikely that it will be adopted for many years to come. Meanwhile the workers seem disposed to meet the companies in a fair spirit, with a view to solving present difficulties. This friendly feeling, however, can scarcely be expected to continue, when the era of cheap labour is inaugurated. Will the Labour war be carried on with the old weapons of the strike and the lock-out, or will the more civilised methods of conciliation and arbitration be preferred? Much depends upon the ability of the workers to grasp in time the significance of the situation, and be prepared with a New Unionism powerful enough to demand and obtain, in the interests of society as a whole, conditions for labour which will make the reappearance of the European slums in South Africa an impossibility.

\section{W. NIDDRIE}

\section{The Agricultural Crisis.}

For a little more than twenty years the agricultural production of America has been keenly competing with that of Europe, and has induced in it a most serious crisis of an entirely different nature from all agrarian crises of past centuries. From all parte of Europe, unless it were some exceptional year like 1897-98, there are heard the laments of landowners presaging the ruin of their economic and social position. Socialists would like to bring about a violent confiscation of private property in land; but the economic crisis with which, during the last twenty years and more, agriculture has been travailing, is of such gravity that it will effect this confiscation by far surer means than any of those which might be applied by socialistic revolutionaries.

Futile in the face of this is all the systematic legislation by which the landed interest, who, in practically every country, have the lion's share of political power, have tried to secure their vantage-ground. 
The wholesale downfall which threatens them has not been averted by the many laws facilitating transfer of landed property, instituting banks of land credit, protecting home raw produce, relieving burdens on landed property, \&c.

The gravity of the agrarian crisis of to-day can best be observed in countries where manufacturing industries are practically non-existent, as is the case with Italy.

From January 1st, 1893, to June 30th, 1896, in consequence of debt incurred through taxation on land and manufactured goods, or through distraint for taxation, 169,973 transfers of land were registered in Italy, equal in value to 7,982,864 lire. Figures like these, remarks Luigi Luzzatti, give rise to melancholy thought on the number of expropriations of small proprietors, over and above these, which have taken place in consequence of ordinary debts.

Luzzatti is perfectly right. ${ }^{1}$ In France, as in England and elsewhere, a far wider conception has prevailed with regard to taxation on land; its incidence has been largely diminished in the case of all proprietors, both small and great.

This provision, however, is absolutely inadequate to save agriculture from the crises afflicting it.

In all countries the total incidence of the tax on land has been reduced to a positive irony, hardly exceeding 3 or 4 francs per hectare of cultivated soil. Were it completely abolished, agriculture would be but little relieved. The nature of the agrarian crisis is such that the maintenance or abolition of the land tax can exercise scarcely any influence whatever.

If we look attentively into all the bulky volumes of the "Agrarian Inquiry" compiled in Italy during the last few years by a Parliamentary Inquiry, we shall find a number of data sufficiently disquieting to the landed interest.

Thus, the medium value of agricultural produce in Italy was reckoned at 5 milliards

Expenses of production reckoned at

60 per cent............................ 3 ,

Net production.......... 2 milliards.

These are very wholesale estimates, but they are accepted by a no less scrupulous statistician than Professor Bodio.

Land tenure in Italy varies greatly according to different districts. In some regions large-scale property preponderates; in others small

1 Luzzatti, as Minister of the Treasury, proposed certain financial measures calculated to save agriculture from such economic crises. These measures consisted in a reduction of the land tax, where it weighcd on small proprietors. That is to say, it was to be abolished in the case of all proprietors of land who paid less than 10 lire of taxes. This reform would affect about $2 \frac{1}{2}$ inillion proprietors, whose aggregate land tax amounted to 11,500,000 lire. (Cf. Esposizione finanziaria dei ministro del Tesoro, per L. LuzzatTi, fatta alla Camera dei Deputati, nella edu a del primo Dicembre, 1897. Roma, 1897.) 
and medium proprietorships are more general. In Southern Italy large estates are the rule, accompanied by all the archaic and odious characteristics of the feudal system. The Northern districts, on the other hand, have been affected by the beneficent influence of modern economy. This variety in the division of property according to geographical distribution tells powerfully on the composition of the rural population, in so far as this consists of owners of land and labourers.

Taking the average of the whole kingdom, for every, 1,000 engaged in agriculture 145 are proprietors. This term, however, has a very wide meaning. For instance, there are more proprietors in Sardinia than in any other part of Italy, namely, 240 per every 1,000 persons of the rural population, yet the economic circumstances of the small Sardinian yeoman are not like those of landed property in Emilia, Marche, or Tuscany, where property is very little subdivided. One of the chief causes of the severe agrarian crises in Sardinia is the excessive subdivision of land.

Fortunately this is not the case in all parts of Italy. The total number of properties in land is a little over 3 millions. In France, on the other hand, Guyot reckons that the holders of landed property now amount to $8,450,000$. Thus, in that country more than one-quarter of the population have a proprietary right in the soil and to land-rent. In Italy, on the other land, but one-tenth of the population, viz. 3 millions out of thirty, have this right. These 3 millions of the Italian population absorb two-thirds of the total agricultural produce of the country.

If this were true-if, that is to say, one-tenth only of the population of Italy, by virtue of owning land, were to succeed in engrossing twothirds of the value of the agricultural produce of the country, then the Marxist theory respecting the social and economic value of landed property would acquire great importance, and its accuracy would be difficult to refute.

While, however, the data we quote are neither exactly erroneous nor fallacious, let us recall the maxim of Rumelin :-That in statistics it is not the eloquent and striking figures that are most important, but rather those that need to have their mouths opened before they can be made to speak. The first thing we have to do is to deduct from that net revenue of 2 milliards accruing to the landed interest about 270 millions for imperial and local taxation, taxes on beasts used in agriculture, that on fuacatico in the rural communes, and other taxes on co-operative societies for irrigation and the like, nor is the list yet exhausted.

It must be remembered that the landowners do not always obtain the market price for their produce, as the middlemen do. Professor Mazzini reckons that the latter get 275 millions. Besides this about 206 millions are paid to tenants.

Thus decimated the net revenue of those 3 million landed proprietors 
becomes reduced to one milliard, 255 millions. Even then we have neglected to mention the heaviest burden on landed property. We have deferred till the last to speak of the debt of mortgage pressing at the present day on the landed interest in Italy.

We cannot consider as a debt of this kind merely the grants issued by the banking institutes of landed credit. These represent only the smallest part of the indebtedness by mortgage, and should now amount to about 800 millions. Besides this we have to take into account, as previously on real estate, another half milliard of land value which has no connection with the three Italian banking institutes of the Act of August 10th, 1893.

The interest-bearing mortgage with which land and house-property in Italy is burdened amounts to 10 milliards at least, besides other 7 milliards of mortgage paying no interest. A good part of the latter is itself a positive and real debt on real estate; and, without wishing to be unjust to the contributor, we must remember that a debt which actually ought to bear interest is made to appear to bear none, and that for the sole purpose of evading the fiscal system of the Italian Government. There is nothing strange in this. No one disputes the superior honesty of the English over that of any other nation. But does not even the Englishman believe that he smoothes out all inequalities in the revenue raised by his own government when he cheats it by every possible device? Such a system in England is so widely diffused that the amount of personal property, judging by the contributions paid to the State, appears less than that in France. Whereas, in reality, French personal property is immensely inferior to that of the English. Hence we are led to believe that a considerable part of the debt of mortgage bearing no interest constitutes in itself a positive and genuine burden on real estate in Italy. But it is impossible here to make any estimate of its magnitude.

This inadequacy of data in Italian statistics necessarily lends a very relative and merely suggestive value to all calculations.

The value of house-property in Italy is 9 milliards. In Bodio's opinion the mortgage debt on all this property cannot be more than 3 milliards. Perhaps this figure is somewhat exaggerated. Anyway such an approximate statement is insufficient to convince us that the greatest part of the mortgage debt is borne by the landed interest. If we take account of such property as has been pledged at the banks of issue, of all those personal bonds which are secured on landed property, but which, for the purpose of evading government dues, do not appear in the sum of the mortgage debt, we may then accept the opinion that the debt really and specifically encumbering landed property is a matter of from 10 to 11 milliards.

Now if, from the net revenue of 1,255 millions which remains, as we have seen, to the owners of Italian soil we take away those other 8 or 9 hundred millions of interest paid on mortgage, what remains is a mere song. 
The actual holders of property in land have but the shadow of possession, and as the fruit of their property at the present day there remains to them but an absurd minimum.

The thought that such a state of things is not confined to Italy is but poor comfort, nay, rather a reason for greater discomfort. Among other instances we may quote that of Russia, where the conditions of national economy have much in common with those of Italy, notably in the overwhelming preponderance of agrarian industry. Here, too, we find absence of prosperity, and in manufacturing industry a development that is anæmic and practically null.

In 1894 the 3 million hectares of landed property belonging to private owners were burdened with a mortgage debt of $1,000,000$ roubles. In connection with this the following argument is put forward by Combes de Lestrade : Assuming that this colossal sum produces no more than $4 \frac{1}{2}$ per cent. interest, and adding to this $\frac{1}{2}$ per cent. of sinking fund, plus $\frac{1}{4}$ per cent. as the quota claimed by the land-bank, we have then 52 million roubles to distribute over 38 million hectares of land. This comes to 1.40 rouble per hectare-which would not be much were it not that, in the mortgage securities, land of all kinds, both good and bad, is included.

An official Russian inquiry estimates the returns on landed property at 4 per cent. But then the net return is so much diminished that the interest on the debt can only be paid by increasing the mortgage, or by drawing the amount from other resources.

Combes de Lestrade, in his recent publication, concludes that it is therefore possible to foresee the time when the creditors in land will be able to take possession of the hypothecated property and become the large landowners of the country. It is not difficult to imagine what, in that case, would become of rural life in Russia.

It matters not whether the writer be a convinced free trader, he is sure to undergo moments of protectionist obfuscation; he fears that it may indeed be the new countries which create conditions so perilous and fearfully disastrous to European agriculture.

But he is at length about to come to himself. At a general meeting of the Knights of Labour, that well-known association of American working men, held in 1895 , it was stated by a member that, though the precise amount of the mortgage debt on landed property in the United States was not known, the fact was any way notorious that it had grown to an extraordinary and ruinously heavy extent; that in thirty-three States it amounted to one quarter of the value of the property, and that therefore a great part of the population was in a financial situation from which there was no possible way out.

The mortgage debt of the United States has since been reckoned at at least 500,000,000 dollars (about 18 milliard francs), without taking account of any other forms of debt. The conditions of agriculture in the United States afford, indeed, little or nothing to attract the envy of European countries. American farmers at the present day discount 
the consequences of the economic process from their contracts for the acquisition of property. A farmer who has purchased an estate without having money enough to pay the whole price, incurs to the extent of his short-coming a mortgage on the land he has acquired. Then this farmer, as a rule more enterprising than economical, proceeds to buy beasts of burden, machines, tools, building materials, ever drawing on the credit conferred by his mortgage as security. When a crisis arises and the price of his produce falls, it becomes impossible for him to pay interest, and he is doomed to forfeit his farm.

Even in England the amount of the mortgage debt is at least equal to 60 per cent. of the value of property in land. If to this we add the taxes directly incurred by the property, we find that the profits reaped on agricultural effort by the occupiers of land are reduced to the veriest minimum.

Wherever this phenomenon is found, whether more or less in degree, namely, that of the occupiers of land receiving on the one hand a very scanty residual profit, and, on the other, owing enormous sums to the owners of personal property, it is evident that it is the latter who, lending capital on mortgage, are the recipients of the entire yearly agrioultural returns. The occupiers of landed property have at the present day practically nothing but the outward show of possession. Theirs are the functions of the French aristocracy on the eve of 1789. Sooner or later they will be despoiled of a social function they have shown themselves inapt to exercise. Little by little the tenure of the soil will slip from the rusty grip of a body which has gone on cultivating it as though living in the darkest period of mediævalism. They have succeeded in but one direction:- the invention of the methods and shifts of exclusivism and protectionism. With these they have succeeded in hindering and paralysing all progress in the technics of production. Such a phenomenon finds a singular counterpart in the course pursued for many a century by China. For many centuries China has reckoned progress solely by her success in inventing means and expedients to dam and check the infiltration of new civilisation.

During that time the landed interests in Italy were thrusting all the burdens of new taxation on to other classes of the body politic, and making lighter those borne by themselves. But in spite of all these bolstering devices, in spite of the landed interest having so odiously squandered that political power they have nearly always monopolised, to-day they have all but touched the ultimate point where nothing remains but ruin.

Giuseppe M. Fiamingo

Translated by C. A. FoLEY 